\title{
Communication Experiences and Self-Consept of Diaspora Afghanistan in Buginese Land
}

\author{
A. Hasan Al Husain ${ }^{1}$, Tuti Bahfiarti ${ }^{2}$ \\ \{a.hasanalhusain@ymail.com ${ }^{1}$, tutibahfiarti@unhas.ac.id $\left.{ }^{2}\right\}$
}

Sekolah Tinggi Agama Islam Al Gazali. JL A. Mappijalan No. 23 Bulukumba Indonesia ${ }^{1}$, Hasanuddin University. Jl. Perintis Kemerdekaan KM 10 Makassar Indonesia²

\begin{abstract}
Immigration is the movement of people from one country to another. Many factors cause immigration change. Refugees as people who bring human rights to other countries and wait for a third country. Indonesia is one of the destinations for refugees, and Makassar is one of the refugee shelters. Afghan refugees are the biggest refugees in Makassar City and Tamalanrea District. The interaction of inhibitions with local communities and refugees is one of the language differences. Negative public view from refugees. This type of research is descriptive qualitative by discussing phenomenology. Based on field facts through observation, interviews, and documentation. The research subjects were several Afghan refugees in Tamalanrea Subdistrict, namely 4 people who had been in Makassar City for 2-5 years as Refugee status. This study discusses exploration in the informant's communication experience. The results of this study indicate that communication experiences are categorized into two, namely pleasant communication experiences and unpleasant communication experiences. The self-image of Afghan refugees is positive and negative, convincing in their self-image, self-image, personality, and independence on the basis of others. The dignity of Afghan refugees from four informants, three have positive self-esteem and one person has negative selfesteem.
\end{abstract}

Keywords: Refugees, Communication Experience, Sel-Image, Self-Esteem.

\section{Introduction}

Immigrants are different with refugees, as the The United Nations High Commissioner for Refugees (UNHCR) limit defines Refugees as someone or group who is forced to flee to save their lives or defend their freedom, but migrants describe anyone who moves, usually across international borders, to join family members who have been abroad, to find livelihoods, to escape natural disasters, or for various other purposes.

Moving individuals carry cultural values and collective memory in an ethnicity called the diaspora. Diaspora according to Paul Gilroy is a relational relationship, the basic factor of character formation is caused by forced ethnic or ethnic distribution. The driving force of the diaspora is a dominant influence, such as war or conflict and describe travel or nomadism. Its relationship with the diaspora driving factors, not only because of war or internal pressure within an ethnic area [1]. 

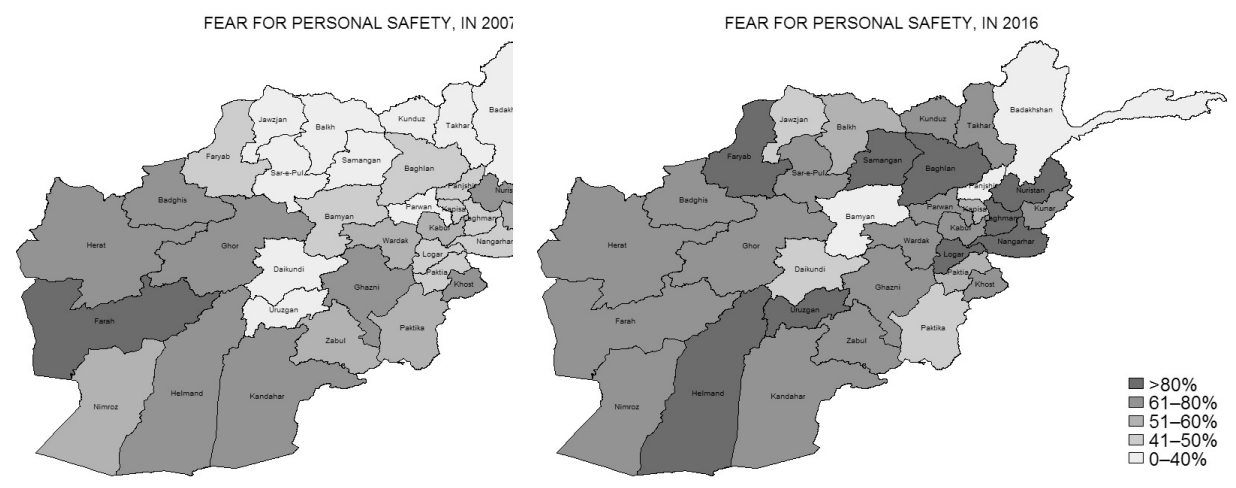

Fig. 1. The Asia Foundation (The Survey of Afghan People) [21]

Since 2015, Makassar has received a large number of displaced and migrant humanitarian migrants from Middle East caused by a civil war that has been going on for two decades. Over the past decade, around 3,870 Afghan migrants have arrived in Makassar under the UNHCR Program. [2] The presence of immigrants from Afghanistan in Makassar City requires them to interact with local residents, and they are required to adapt to the Makassar socio-cultural environment. In society wherever, cultural contact cannot be avoided so that intercultural relations become absolutes for the smooth interaction and communication in society and harmony and inter-ethnic relations is the absolute necessity to live a harmonious life. [3] Afghan refugees who come to Indonesia with a very diverse culture. The majority of ethnic groups in the city of Makassar are Hazara ethnic and become ethnic minorities within the Makassar City community. Their identity as migrants with many differences from the local community is reference for these refugees to construct their new identities.

Table 1. Number of Refugees under the supervision of RUDENIM Makassar for the period of January

\begin{tabular}{llllll}
\hline \multirow{2}{*}{ No. } & \multirow{2}{c}{ Nationality } & \multicolumn{2}{c}{ Jantil June 2019 [20] } & \\
\cline { 3 - 5 } & & $\begin{array}{l}\text { Total Man } \& \\
\text { Woman }\end{array}$ & Man & Woman & Equal \\
\hline 1 & Afghanistan & 1129 & 956 & 231 & 2316 \\
2 & Myanmar & 243 & 134 & 61 & 438 \\
3 & Somalia & 213 & 90 & 64 & 367 \\
4 & Sudan & 83 & 56 & 12 & 151 \\
5 & Iran & 243 & 36 & 17 & 296 \\
6 & Pakistan & 27 & 26 & 20 & 73 \\
7 & Irak & 39 & 33 & 9 & 81 \\
8 & Srilangka & 34 & 14 & 14 & 62 \\
9 & Ethopia & 30 & 17 & 8 & 55 \\
10 & Palestina & 12 & 5 & 3 & 20 \\
11 & Yamen & 0 & 5 & 0 & 5
\end{tabular}




\begin{tabular}{llllll}
12 & Eritria & 3 & 1 & 0 & 4 \\
13 & Egypt & 0 & 1 & 0 & 1 \\
14 & Syiria & 0 & 0 & 0 & 0 \\
15 & Nepal & 0 & 0 & 0 & 0 \\
16 & Thailand & 0 & 1 & 0 & 1 \\
& Equal & 2056 & 1375 & 439 & 3870 \\
\hline
\end{tabular}

The Afghan Diaspora influences the IDP's identity while living in Makassar City. Affects many things including patterns of interaction with people living in the area. Self-concept is all our perceptions of ourselves from all aspects, both physical, psychological, social, based on experience and interaction with others. In LittleJohn [4] said that the Diaspora is closely related to media and culture which has become a critical study in the minority community in the west. Then this phenomenon developed throughout the world due to conflicts and wars that occurred, as well as conflicts that occurred in Palestine. Culture becomes an identity that is constructed in identity [5] is the building of self-identity, showing who we really are and our similarities with a number of people and what distinguishes us from others. In this paper, we will analyze why Afghan refugees are not too open and lack interaction with local residents.

Afghan refugees are the biggest refugees in Makassar and Tamalanrea Subdistrict, there are as many as. The existence of cross-cultural communication that occurs in the environment can be seen in the patterns of language and informs of activity. Behavior that serves as a model for self-adjusting actions and communication styles, this allows people to live in society in a particular geographical environment. Culture is also concerned with the properties of material objects that play an important role in everyday life. Culture inevitably influences us from the womb to death. barriers to interaction with the local community and refugees, one of which is the difference in language and the negative public view of refugees about the religious sect [6].

On average, those who live in the city of Makassar move on their own without family and of course they have experienced many events until they become refugees in Indonesia. In countries that are very different from their home countries, they are required to live, communicate and interact with other refugees from various countries that have different cultures and languages, such as Myanmar and other conflict countries. Because the core of cross-cultural communication is the growing harmony in the social environment of the community.

Experience in communication is considered to have an influence on self-concept. Because self-concept is all our perceptions of ourselves from every aspect, both physical, psychological, and social-based on experience and interaction with others. In the self-concept, the researcher sees from two components, namely self-concept, namely self-image and selfesteem. In this study, it will be seen how refugees from Afghanistan see themselves as human beings who are physically related to attributes, who have quality, and are characteristic and possess identity both socially and personally. While in self-esteem, researchers see how Afghanistan respects and values itself, then believes that it respects or not and what social behavior is needed by knowledge who knows.

Mulyana explained that the phenomenology approach was included in a subjective or interpretive approach [7] and then Maurice Natanson said that the term phenomenology can be 
used in generic terms to refer to all the perspectives of the social sciences that place human consciousness and its subjective meaning as a focus for understanding its social actions [7]. "The phenomenologist is concerned with understanding human behavior from the actor's own frame of reference". This requires the unity of the subject of the researcher with the supporting subjects of the research object. The subject matter of researchers in the field of life is one of the main characteristics of research with a phenomenological approach. The phenomenology used in this study in Alfred Schutz's perspective emphasizes the importance of intersubjectivity [8].

The concept of symbolic interaction theory was introduced by Herbert Blumer in Raho [22] around 1939. Within the scope of sociology, this idea was actually already put forward by G.H Mead [22], but later modified by Blumer to achieve certain goals. This theory has a good, but not too deep and specific idea as proposed by G.H. Mead [22].

According to the theory of symbolic interaction, social life is basically human interaction using symbols, they are interested in the way humans use symbols that represent what they mean to communicate with each other. And also, the influence caused by the interpretation of these symbols on the behavior of the parties seen in social interactions [9].

\section{Research Method}

This type of research is descriptive qualitative with a phenomenological approach. Based on field facts through observation, interviews and documentation. The research subjects were a number of Afghan refugees in Tamalanrea District, namely 4 people who had been in the city of Makassar with status as refugees for 2-5 years. This study focuses on exploring the experiences of informants in communicating with local communities. For research purposes, there are the following questions to answer this research, namely how to experience the communication of the Afghan diaspora in Tamalanrea sub-district which results in a selfimage of him as a refugee. As a research method, phenomenology is a way of building an understanding of reality. This understanding is built from the perspective of social actors who experience events in their lives. His understanding achieved at the personal level is a personal construction of reality or construction of Subjectivity.

The main assumption of phenomenology is that humans actively interpret their experiences in giving meaning to something that is natural. Therefore, interpretation is an active process that gives meaning to something that is experienced by humans. In other words, understanding is a creative action that is action towards meaning. The phenomenology formulated by Husserl at the beginning of the 20th century emphasizes a world that presents itself to us as humans [10]. The aim is that we return to the object itself as to what appears to us and convey or confine what we already know about them. In other words, phenomenology is attracted to the world as experienced by humans with special contexts, at special times, more than abstract statements about the nature of the world in general [11].

There are three basic principles of phenomenology according to Schutz which Stenly Deetz concluded, first knowledge is found directly in conscious experience. We will know the world when we relate to the experience itself. Second, the meaning of objects consists of the strength of objects in one's life. How we relate to things determines meaning for us. And the third is Language is a vehicle of meaning. We experience the world through the language used to define or interpret the world [11]. 


\section{Result and Discussion}

\subsection{Communication Experience of Afghan Refugees in Tamalanrea District}

Experience in communication is something that has been experienced by someone in communicating both with himself and others. Through experience, each individual gets a new knowledge that results in actions for him to act in the future if faced with these conditions. Knowledge is based on the awareness that forms a meaning. Awareness and meaning that encourage individuals to do an action or behave something [11]. Experience in the form of phenomena that can refer to an event, including events in the communication process [11]. The experience is in the form of information or it can be in the form of a particular message. This information will later be processed into knowledge. Thus, various events in phenomena in individuals ultimately produce knowledge [11].

The experience of communicating experienced form of verbal communication and nonverbal communication, where the communication experience has an impact on creating awareness of the conditions of refugees from Afghanistan itself. In this study, the experience of communication experienced by refugees from Afghanistan relates to aspects of communication, including the process of meaningfulness or symbols. Thus, the experience of communicating refugees from Afghanistan is one of the focuses in this study, can be described as a communication experience that is part of the awareness of refugees from Afghanistan in conducting interactions with fellow refugees in the Tamalanrea Subdistrict, as well as with local communities living near refugees.

Experience will be categorized by each refugee through the characteristics of his experience based on the meanings obtained [11]. In line with this study, the communication experiences of Afghan refugees will be categorized into certain types of experiences, namely pleasant (positive) communication experiences in the form of acceptance, motivation, friendship, and learning. While unpleasant (negative) communication experiences in the form of ignorance, loss of communication, discrimination or differences in treatment, verbal and nonverbal abuse.

Experience can be called a positive or pleasant communication experience when the content, context, and impact of the communication process experienced are understood and felt by actors as direct empowerment [11]. Based on the results of this study, positive communication experience in the form of acceptance is experienced by four researcher informants, namely in the form of acceptance in society. Acceptance was shown when informants were permitted to join in the same activities as the community, namely exercising together in the same field. While the positive communication experience in the form of motivation was experienced by four informants in interacting and communicating with other refugees, where they supported and motivated other refugees, because of the same status of those who became refugees without families in other countries.

The experience of positive communication in the form of friendship was experienced by four informants in establishing friendships with fellow refugees, which was seen when researchers observed sports and parks at Hasanuddin University, the four informants were always with other refugees. While friendship with the local community or the Indonesian community, three informants had friendships with Indonesian people who were intertwined with informants' sports activities in the Tamalanrea field, but not with one researcher informant who did not have or establish friendships with the local community.

The positive communication experience consisting of learning was received by two people from the Informant, where they got compilation learning with the local community, 
namely learning Indonesian. The friendship between the two informants and their Indonesian friends gave informants in English that were used by Indonesians. While the communication experience is negative, based on the results of this study, in the form of ignorance experienced and felt by one informant, where the experience is in the form of attitude changes that occur in the surrounding community as ignorant.

While the miss communication experience has been experienced by two informants, namely miss communication with refugees from various countries who cannot use English or Indonesian, so informants sometimes use body language which sometimes causes confusion with informants. The loss of communication with the community environment has been experienced by one informant, namely the lack of understanding of the meaning of words from the Indonesian language, so he has aroused anger from an Indonesian friend from the research informant. Negative communication experience in the form of discrimination or difference in treatment has been felt by two informants from the community, namely discrimination based on informants 'physical information, namely the difference in the skin color of informants' informants, which makes informants not only distinguished by skin color. While one informant was discriminated against because of the informants' belief in Islam and Shiite schools, where the research informants were not permitted to worship in a mosque.

The experience of negative communication in the form of verbal and nonverbal harassment was experienced by three informants, namely by calls made frequently by Indonesians to people who came from outside Indonesia such as "Weh Mister", "Mister" and English words which meant rude informants like "Bad Name" for them, so the informant isn't comfortable with such a call.

\subsection{Self Image of Afghan Refugees in Tamalanrea District}

Undergoing work in self-image refers to quality, attributes, and characteristics for himself. Whether we focus on certain situations where people identify with underlying roles or social and personal identities, self-perception involves more than the social location [12]. According to [13], self-esteem and self-image have a major influence on interpersonal communication patterns, self-image (self-image) is a picture of someone's self [11].

The four informants explained that they had good and good personalities, so they did not have [11] problems regarding their personalities. Even one of the informants said that if he was evil, then people would be mean to him, whereas if he was good then people would be kind to him. This research also shows how informants view themselves or their image as refugees. Three informants have a positive self-image as refugees. This was seen when the informant gave a statement that the refugees were legal, where refugees had signs of refugees as their identity in Indonesia, not just cards, one informant also assumed that the refugees were right, where if they still decided to stay in their country then will be killed like a criminal.

While one informant said that refugees were people who were just waiting and people who could not do anything, the statement showed that one researcher informant had a negative view of his status as a refugee. Self-image is also influenced by the views of others, such as two informants who say that in their view there are Indonesians who have a negative view of refugees, one of them is using refugees as criminals, not only criminals but also negative views on the flow of informants Islamic religious "Syiah", who are seen negative by some people. Although the two informants did not know what Indonesians saw about them, the two informants only assumed that Indonesians were good people. 


\subsection{Self-Esteem of Afghan Refugees in District Tamalanrea}

One component of self-concept is self-esteem. Self-esteem is an affective component. Self-esteem according to [14] is an evaluation or positive or negative evaluation of this self [15]. According to Coopersmith in Burns [16] self-esteem is how one views himself as someone who is valuable or not. A sense of self-esteem is the level at which someone feels positive or negative about their characteristics [17]. In other words, self-esteem is an individual's assessment of himself which is expressed through his daily behavior.

Self-esteem seen in this study consisted of positive self-esteem and negative self-esteem. Self-esteem is one of the best information providers for refugees. All informants had feelings that were not happy to be refugees, regardless of family, unpleasant past experiences in their home countries, no jobs, this was a reason not to forgive informants, but the current situation and conditions of the research informants' self-esteem were seen from the way they accept or not accept their lives now. As Rogers said, positive self-esteem is also indicated by acceptance. According to Rogers, acceptance is an award that is friendly to someone as a person with valuable complete self-confidence without regard to conditions, behavior, and feelings. Acceptance means respecting and liking that person as a different person, allowing him to have his own feelings [18].

Three informants tried and accepted their situation, they also had to feel satisfied and comfortable with their situation as refugees, because they had no other choice. While an informant felt unhappy and dissatisfied with his life, he considered the life he was living in now to be meaningless, so it appeared that he did not accept the situation and conditions of his life now. A person's self-esteem is also indicated whether he thinks he is valuable or not. Three of the informants considered themselves valuable, where when they could not get a job, they filled their spare time in a positive way, such as one of the informants who studied at "Sekolah Pengungsi", specifically for refugees and learning was done through internet media, and one informant learn many things to add to their skills, such as learning Indonesian, or other skills. But one informant thought he was useless because he could not do something as a refugee.

According to William D. Brooks \& Philip Enrich [13], self-esteem and self-image have a major influence on interpersonal communication patterns, self-esteem (self-esteem) is a form of human need to feel that he is needed and valuable for others [11]. Based on this study, three informants were not only considered valuable and useful, but also useful and needed from others, as often as they met with school students who learned English for them, and those who enjoyed helping these students. The third informant also has an Indonesian friend. Likewise, the compilation of researchers communicates and talks with them, they show a willingness to meet and communicate with researchers if researchers need their help. Unlike one informant who rarely interacts with other people, this makes the informant not have an Indonesian friend. The results of the self-concept produced by the informants produced actions to interact with local communities and fellow refugees. 


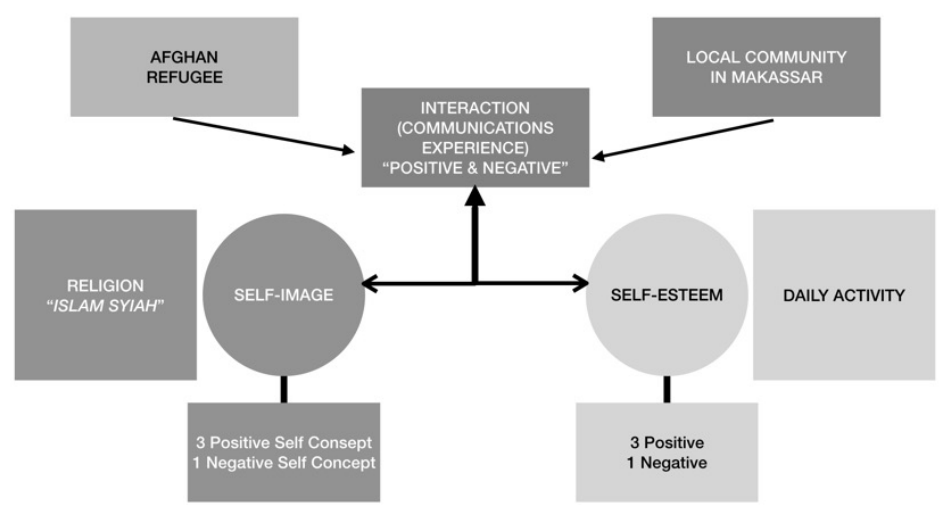

Fig. 2. Mapping Analyst

\section{Conclusion}

Experience of communication with fellow refugees and with the community of around two types, namely a pleasant (positive) communication experience, namely acceptance, motivation, friendship, learning, and communication activities that are not pleasant (negative) consisting of being ignored, losing communication, differences or differences in care, verbal and nonverbal abuse.

Self-image in this study seen from physical characteristics, personal personality, self as a refugee and self-view based on the views of others from the image of Afghanistan about refugees divided into two, positive self-image or negative self-image. Positive self-image can be seen from the compilation of people who see them as someone who is negative, but they still see themselves as positive refugees. Self-esteem from this study, three research informants had positive self-esteem and one person had negative self-esteem. Self-esteem in this study is seen from the acceptance of themselves as refugees, consider themselves valuable and useful, use themselves as needed or benefit others, show positive self-esteem for refugees. Negative self-esteem for Afghan refugees, where there is no self-acceptance of current conditions and situations, understanding oneself is not useful for themselves or others.

\section{References}

[1] S. Helmreich, "Kindship, Nation, and Paul Gilroy's Concepts Diaspora," Diaspora: A Journal of Transnational Studies, Vol. 2, no. 2 (1992)

[2] RUDENIM .: "Data Pengungsi Di Kota Makassar," Rumah Detensi Imigrasi Makassar, Makassar. (2019)

[3] Bbarth, F, Etnik Group and Boundaries "The Social Organization of Culture Difference, Massachusetts, Boston: Universitdsforlaget (1969)

[4] Foss, L. J. a. K. A.: Encyclopedia of Communication Theory, United States of America: SAGE Publications, Inc (2009)

[5] Barker, C.: he Sage Dictionary of Cultural Studies, London: Sage Pub (2004)

[6] Lestari, I.: "Pengungsi Dan Pencari Suaka Afganistan Dengan Masyarakata Lokal Di Kota 
Makassar: (Suatu Analisis Efektivitas Komunikasi Antar Budaya)," Kareba, Vol. 4. no. 2 (2015)

[7] Mulyana, D.: Ilmu Komunikasi, Suatu Pengantar, Bandung: Remaja Rosdakarya (2001)

[8] Taylor, B. d.: Metodologi Penelitian Kualitatif, Bandung: Remadja Karya (1975)

[9] Friends, B. a.: Handbook Ilmu Komunikas, Bandung: Nusa Media (2014)

[10] Nurhadi, F.: Teori-teori Komunikasi (TeoriKomunikasi Dalam Perspektif Penelitian Kualitatif), Ghalia Indonesia p. 36. (2015)

[11] Foss, S. W. L. J. \&. K. A.: Teori Komunikasi "Theories Of Human Communications" Jakarta: Salemba Humanika. p. 38.(2009)

[12] Wirman, W.: Citra \& Presentasi Tubuh Fenomena Komunikasi Perempuan Bertubuh Gemuk., Pekanbaru: Alaf Riau p. 69.(2006)

[13] Hewit, J. P.: Self And Society : A Symbolic Interactionist Soocial Psychology., Boston: Allyn and Bacon p. 129. (2003)

[14] Emert, D. B. W. d. P.: Konsep Diri Manusia., Jakarta: EGC (1976)

[15] UI, T. P. F. P. : Psikologi Sosial, Jakarta: Salemba Humanika p. 57. (2011)

[16] Wrightsman, D. D. d. S.: Social Psychology in the 90's. (2nd), California: Wadsworth Publishing Company, Inc (1992)

[17] Burns, R. B.: Konsep Diri: Teori, Pengukuran, Perkembangan dan Perilaku, Jakarta: Arcan (1993)

[18] Adelia, A. d. S.: "Konsep Diri Wanita Model Fashion Show Di Kota Pekanbaru," Jurnal Online Mahasiswa Fakultas Ilmu Sosial dan Ilmu Politik (2016)

[19] Rogers, C. R.: On Becoming a Person., Jakarta: Pustaka Pelajar (2012)

[20] Husain, A. H. A.: "Identitas Diaspora Afghanistan (Studi Fenomenologi Rekonstruksi Identitas Diri Diaspora Afghanistan dalam Berkomunikasi dengan Masyarakat Bugis-Makassar)," Universitas Hasanuddin, Makassar (2019)

[21] Foundation, T. A. : "Afghansitan in 2016: A Survey of the Afghan People," The Asia Foundation, 14 October 2019. [Online]. Available: https://asiafoundation.org/publication/afghanistan-2016survey-afghan-people/. (2019).

[22] Raho, B. and SVD.: Teori Sosiologi Moderen, Jakarta : Prestasi Pustakarya p. 107. (2007) 